... entre o filosófico, o ético, o antropológico...

\title{
Roberto Goto
}

$\mathrm{V}$

ário é o conteúdo da presente edição de Filosofia e Educação, não sendo possível estabelecer uma unidade temática, embora entre os textos possam ser vislumbrados aspectos e elementos comuns. Daí o título múltiplo, compósito, reticente hesitante mesmo; ciente de seu caráter contingente, reconhece-se como apenas uma entre alternativas possíveis e fortuitas, ao mesmo tempo, contudo, em que aponta para o leque de interesses e tendências que compõem a variedade deste número.

Abre o leque um artigo cujo assunto fala mais de perto ao escopo da revista. Adotando premissas deleuzianas a respeito da definição do pensar e do filosofar, Danilo Melo propõe que o ensino de Filosofia seja praticado de modo a fazer irromper uma "experiência de pensamento" que possibilite a perspectiva, tanto a "ensinantes" quanto a "aprendentes" - sejam eles crianças, jovens ou adultos -, de mudar seus "modos habituais de compreenderem e se relacionarem com a diversidade do mundo".

Erikson de Carvalho Martins e Gilberto Lacerda dos Santos discutem categorias de pesquisa associadas à epistemologia qualitativa, à fenomenologia e à pesquisa-ação, pretendendo uma revisão teórica que levante convergências e divergências entre elas. Concluem que todas as três "tipologias de pesquisa" tendem a construir processos de investigação mais interpretativos e reflexivos, flexíveis e adaptáveis, prescindindo de instrumentos padronizados, 
pois consideram que "cada problema de pesquisa demanda seus próprios procedimentos e instrumentos".

Samuel Molina Schnorr e Carla Gonçalves Rodrigues avaliam o ensino de Ciências na esteira de categorias foucaultianas e deleuzianas a respeito das relações entre sociedade, ciência e tecnologia, e, sem pretender apresentar respostas definitivas para as questões que trazem para análise e debate, apostam num "pensamento científico que desenvolva a produção de novos sentidos", bem como numa "prática educacional" que abandone as "convenções, o já dito, [o] normalizado".

Antonio Carlos Souza trata da ética marxista, caracterizando-a como teórica e prática, "crítica, educativa, propositiva, utópica", mas não normativa, tampouco prescritiva. Embasada teórica $\mathrm{e}$ politicamente no estudo da História, tal como concebida e julgada por Marx e Engels, essa ética "procura explicar porque em determinada época [...] predominam princípios e normas de comportamento", assim como a razão pela qual "dão lugar a outros princípios".

Luiza de Freitas Nunes revisita o clássico tema do Eros socrático-platônico para dele aproximar as proposições pedagógicas de Rubem Alves. Como mediação interpretativa, recorre à ideia do amor erótico como incontrolável e indomável, cuja expressão vai buscar em Comte-Sponville ("não amamos o que queremos, mas o que desejamos [...] e que não escolhemos"). No entanto, não acompanha Alves na analogia entre o ato sexual e o educativo, entre o inseminar e o ensinar, pois considera que "o desejo já é a semente que plantamos e é ele que faz com que a inteligência e o conhecimento sejam estimulados". 
Por seu turno, Silvio Sánchez Gamboa passa em revista mais de três mil anos de História para levantar as múltiplas formas de conhecimento e dissertar sobre as diferenças não só entre elas como entre conhecimentos e saberes, avançando para a discussão sobre as relações que aquelas modalidades entretêm com a formação tanto do pesquisador quanto do educador. Termina, no contexto da atualidade brasileira, por expor uma série do que designa como aporias. Uma delas diz respeito ao desafio que hoje se apresenta ao educador na condição de uma dupla necessidade: a de, por um lado, dominar "saberes cada dia mais abundantes, dispostos nas linhas de consumo e nas redes de informação", e, por outro, qualificar criticamente esses saberes a fim de encontrar "respostas válidas" aos problemas que enfrenta em sua prática social e, além disso, de realizar "seus compromissos históricos de potencializar a sociedade do futuro".

Fecha esta mostra plural o texto ensaístico de Rita Ribeiro Voss, que retoma conceitos filosófico-antropológicos por vezes opositivos, como os de natureza e cultura, Cultura e culturas, universalismo e relativismo, hominização e humanização, para explorá-los numa reflexão sobre a formação humana. Reconhecendo que "não é possível nenhum humano se tornar propriamente humano sem realizar as potencialidades latentes da espécie", considera que a "Cultura estrutura a condição humana", ao mesmo tempo em que "as culturas são versões possíveis da vida no mundo". Defende que "não é possível estabelecer uma hierarquia entre as culturas", opinando que "não são as sociedades ocidentais que normatizarão e civilizarão as sociedades simples". Pondera que a formação humana "encerra a noção de condição antropológica do sapiens, natural e cultural e, ao mesmo 
tempo, uma ética encarnada, imanente à vida, à experiência, à diversidade humana e cultural". Levada em conta tal condição, "pensar a formação humana" nesse quadro "talvez signifique abandonar a ideia de que só as escolas têm legitimidade para a tarefa de educar". 